\title{
What Works in Securities Laws?
}

\section{Citation}

La Porta, Rafael, Florencio Lopez-de-Silanes, and Andrei Shleifer. 2006. "What Works in Securities Laws?" The Journal of Finance 61 (1) (January 20): 1-32. Portico. doi:10.1111/ j.1540-6261.2006.00828.x.

\section{Published Version}

doi:10.1111/j.1540-6261.2006.00828.x

\section{Permanent link}

http://nrs.harvard.edu/urn-3:HUL.InstRepos:27867135

\section{Terms of Use}

This article was downloaded from Harvard University's DASH repository, and is made available under the terms and conditions applicable to Other Posted Material, as set forth at http:// nrs.harvard.edu/urn-3:HUL.InstRepos:dash.current.terms-of-use\#LAA

\section{Share Your Story}

The Harvard community has made this article openly available.

Please share how this access benefits you. Submit a story.

Accessibility 
NBER WORKING PAPER SERIES

WHAT WORKS IN SECURITIES LAWS?

\author{
Rafael La Porta \\ Florencio Lopez-de-Silanes \\ Andrei Shleifer \\ Working Paper 9882 \\ http://www.nber.org/papers/w9882
}

\author{
NATIONAL BUREAU OF ECONOMIC RESEARCH \\ 1050 Massachusetts Avenue \\ Cambridge, MA 02138 \\ July 2003
}

We are grateful to the Inter-American Development Bank, the Gildor Foundation, the BSI Gamma Foundation, the NSF, the International Institute for Corporate Governance at Yale University, and the Doing Business project of the World Bank for financial support, to Alfredo Larrea-Falcony and Qian Sun for significant contributions to this work, to Constanza Blanco, John C. Coates IV, Luis Leyva Martinez, Carlos Orta Tejeda, Tuffic Miguel Ortega, Jorge Gabriel Taboada Hoyos, Annette L. Nazareth, and Robert Strahota for assistance in developing the questionnaire, to Douglas Baird, Frank Easterbrook, Richard Epstein, Edward Glaeser, Lawrence Katz, Kevin Murphy, Eric Posner, and Richard Posner for helpful comments, and to Jeffrey Friedman, Mario Gamboa-Cavazos, Anete Pajuste, and Vasudev Vadlamudi for excellent research assistance. The data used in this paper can be downloaded from http://post.economics.harvard.edu/faculty/shleifer/papers/securities_data.xls. The views expressed herein are those of the authors and not necessarily those of the National Bureau of Economic Research.

C2003 by Rafael La Porta, Florencio Lopez-de-Silanes, and Andrei Shleifer. All rights reserved. Short sections of text, not to exceed two paragraphs, may be quoted without explicit permission provided that full credit, including (C) notice, is given to the source. 
What Works in Securities Laws?

Rafael La Porta, Florencio Lopez-de-Silanes, and Andrei Shleifer

NBER Working Paper No. 9882

July 2003

JEL No. G15, G18, G3, G22, P5

\section{$\underline{\text { ABSTRACT }}$}

We examine the effect of securities laws on stock market development in 49 countries. We find almost no evidence that public enforcement benefits stock markets, and strong evidence that laws facilitating private enforcement through disclosure and liability rules benefit stock markets.

Rafael La Porta
Harvard University
M7 Littauer Center
Cambridge, MA 02138
and NBER
rafael_laporta@harvard.edu

Andrei Shleifer

Harvard University

M9 Littauer Center

Cambridge, MA 02138

and NBER

ashleifer@harvard.edu
Florencio Lopez-de-Silanes

Yale School of Management

135 Prospect Street

P.O. Box 208200

New Haven, CT 06520

and NBER

florencio.lopezdesilanes@yale.edu 


\section{Introduction.}

In this paper, we examine securities laws of 49 countries, focusing specifically on how these laws regulate the issuance of new equity to the public. Security issuance is subject to the wellknown "promoter's problem" (Mahoney 1995) - the risk that corporate issuers sell bad securities to the public - and as such is covered in all securities laws. ${ }^{1}$ We analyze the specific provisions in securities laws governing initial public offerings in each country, examine the relationship between these provisions and various measures of stock market development, and interpret these correlations in light of the available theories of securities laws.

Our analysis draws on a theory of social control of business when both markets and governments are subject to failure (Djankov et al. 2003). According to this theory, the efficiency of alternative strategies of such control -- from private orderings, to private litigation over contracts and torts, to still private litigation over public statutes, to government regulation, to state ownership - is determined by the tradeoff between controlling market and government failure. More interventionist strategies, such as regulation or state ownership, might limit market failure more effectively, but are also more vulnerable to government failure. The optimal policy minimizes the total social costs of market and government failure.

For securities markets, this approach can be distilled down to three broad hypotheses concerning optimal public policy. Under the the null hypothesis, associated with Coase (1960) and Stigler (1964), the optimal government policy is to do nothing. The securities law is irrelevant or even damaging. Securities transactions take place between sophisticated issuers and investors.

\footnotetext{
${ }^{1}$ Teoh et al. (1998) and Dechow et al. (1996) present evidence consistent with the view that US firms manipulate accounting figures to raise capital on favorable terms. Leuz et al. (2002) show that earnings' manipulation is more extensive in countries with weak investor protection.
} 
Issuers, auditors, and underwriters have reputational and legal reasons, grounded in contract and tort law, to certify the quality of securities being offered to investors, so as to receive higher prices. Investors have an interest to become informed, and to buy securities underwritten by reputable firms, so as to avoid being cheated. These market and general legal mechanisms suffice for securities markets to prosper. Securities law is either irrelevant (to the extent that it codifies existing market arrangements or can be contracted around), or damaging, in so far as it raises contracting costs and invites political interference in markets (Easterbrook and Fischel 1984, Macey 1994).

The other two hypotheses hold that "law matters." Reputations, contract, and tort law are insufficient to keep promoters from cheating investors because the payoff from cheating is too high and because private litigation is too expensive and unpredictable to serve as a deterrent. To reduce the enforcement costs and opportunistic behavior, the government can introduce a securities law specifying the contracting framework. ${ }^{2}$ The two alternative hypotheses differ in how much government intervention such a framework would optimally call for.

Under the first alternative, which we call the private enforcement hypothesis, the principal benefit of the securities law is the direct reduction in the costs of private contracting. According to this hypothesis, the law can standardize securities contracts (by, for example, mandating disclosure in a prospectus) and clarify liability rules for inaccurate or incomplete disclosure to investors. Without standardized contracts, litigation is governed by contract and tort law, with grave uncertainty about outcomes because such matters as intent and negligence need to be sorted out in court (Easterbrook and Fischel 1984). Securities law can structure contracting and litigation by

\footnotetext{
${ }^{2}$ See Landis (1938), Friend and Herman (1964), Coffee (1984 ,1989, 2002), Simon (1989), Mahoney (1995), Fox (1999), Stulz (1999), Black (2001), Beny (2002), and Reese and Weisbach (2002). Barth et al. (2003) make an empirical case for the benefits of government regulation of banking.
} 
explicitly describing the obligations of various parties and burdens of proof, thereby reducing the costs to them and to the court of establishing liability. With standardized contracts and litigation, the costs of enforcing contracts privately decline, benefitting markets. ${ }^{3}$

Under the final, public enforcement hypothesis, even with a securities law private enforcement incentives are often insufficient to elicit honesty from issuers, and a public enforcer, such as a Securities and Exchange Commission, is needed to support trade. Public enforcement might work because the enforcer is independent and focused and so can regulate markets free from political interference, because the enforcer can introduce regulations of market participants, because it can secure information from issuers and market participants - through subpoena, discovery, or other means - more effectively than private plaintiffs, or because it can impose sanctions. ${ }^{4}$ Under this hypothesis, the strength of public rather than private enforcement mechanisms introduced by securities laws is most beneficial for market development.

To distinguish these three hypotheses, we cooperated with attorneys from 49 countries to assemble a data base of rules and regulations governing security issuance. We used the data to produce quantitative measures of security laws and regulations, with a focus on private and public enforcement. Finally, we examined the relationship between our measures of securities laws and a number of indicators of stock market development. In the analysis below, we first motivate our data collection effort using an example of an actual dispute, then present the data on securities laws around the world, and finally investigate if and how these laws matter for market development.

\footnotetext{
${ }^{3}$ This view is developed in Black and Kraakman (1996), Hay, Shleifer and Vishny (1996), Hay and Shleifer (1998), Glaeser and Shleifer (2001, 2002), and Bergman and Nicolaievsky (2002).

${ }^{4}$ These themes are developed in Landis (1938), Becker (1968), Polinsky and Shavell (2000), Glaeser, Johnson and Shleifer (2001), Glaeser and Shleifer (2003), and Pistor and Xu (2002).
} 


\section{A Motivating Example.}

We focus on the agency problem between prospective investors in an initial public offering and the "promoter" who offers shares for sale. In modern days, this promoter is usually the owner or founder of a private company acting in concert with his distributors (or underwriters) and accountants, but at least some of the law developed historically as a way to control share sales by specialized promoters, who bought companies and then sold their equity to the public (Mahoney 1995). The promoter's problem is fraught with potential conflicts of interest: the promoter wants to sell the shares at the highest possible price while concealing bad information about the company and diverting its cash flows and assets to himself. Both the adverse selection and the moral hazard problems are severe, and if not addressed can severely undermine - possibly stop - fund-raising in the stock market.

Grossman and Hart (1980) show, however, that with perfect law enforcement (i.e., automatic sanctions for not telling the truth), promoters have an incentive to reveal everything they know, at least in a particular model. The reason is that, without such revelation, potential investors assume the absolute worst. To the extent that the circumstances of the company are better or conflicts of interest less severe, promoters have every reason to disclose them, and they cannot say anything more optimistic than the truth because of the automatic sanctions. Grossman and Hart also point out that, without perfect enforcement, these favorable results for the market solution do not hold.

Contrast this theoretical paradigm with an actual example of a securities issue from the Netherlands (Velthuyse and Schlingmann 1995). In 1987 and 1988, a Dutch Bank, ABN Amro, underwrote some bonds of Coopag Finance BV, a Dutch financial company wholly owned by Co-op AG, a diversified German firm. The bonds were guaranteed by Co-op AG. The prospectus was 
drafted in accordance with the requirements of the Amsterdam Stock Exchange and included audited annual accounts provided by the issuer to ABN Amro. In conformity with the law on annual accounts, the (consolidated) financial statements included in the prospectus omitted 214 affiliated companies of Co-op AG with debts of DM 1.5 billion. Shortly after the issue, Dutch newspapers published negative information about Co-op AG and the bond prices of Coopag Finance BV plummeted. The creditors of Coopag Finance sued the underwriter, ABN Amro, for losses due to its failure to disclose material information about the finances of Co-op AG. ABN Amro claimed in response that "the damages, if any, did not result from the alleged misleading nature of the prospectuses..." but rather from unfavorable events that took place after the offering. In addition, the distributor argued that "an investigation by ABN Amro, however extensive, could not have led to the discovery of deceit, because even the accountants appeared not to have discovered in time that something was wrong...” (Velthuyse and Schlingmann 1995, p. 233). The successive Dutch courts, however, ruled the distributor liable, and recognized explicitly that its duty, in presenting the prospectus to investors, went beyond merely relying on the information provided by the issuer. Instead, to avoid liability, the Supreme Court ruled that a distributor must conduct an independent investigation of the issuer and prove that it cannot be blamed for the damages caused by the misleading prospectus.

As this example illustrates, a country as developed as Holland, as recently as 15 years ago, did not have a legal framework in place to guarantee full disclosure as predicted by Grossman and Hart (1980). Some of the differences between the example and their model are worth emphasizing. First, neither the issuer's nor ABN Amro's reputation was evidently sufficient to ensure full disclosure. Second, the problem for private enforcement was not that of inaccurate disclosure -- in 
fact the issuer complied with the affirmative disclosure requirements, but rather the omission of material information from the prospectus. This omission did not cause investors to assume the worst; after all, they bought the bonds. Third, this omission raised the question for the court of whether the distributor or the issuer was liable, with the distributor rather than the bankrupt issuer having the assets to compensate investors. Fourth, and perhaps most importantly, the court had to resolve the crucial question of the standard of liability for the distributor, namely what were its affirmative obligations to investors. The court did not presume, as in the model, that failure to disclose automatically caused liability. Resolving this issue required extensive, and expensive, litigation, leading to a particular standard of care. These differences between the case and the

model suggest that in reality, enforcement of good conduct might be costly, and hence we should not necessarily expect efficient outcomes from unregulated markets.

This enforcement-based reasoning forms the analytical foundation of the case for securities laws. Market mechanisms and litigation supporting private contracting may be too expensive. Since investors, on average, are not tricked (this is not an issue of market efficiency), they pay lower prices for the equity when they are unprotected, and the amount of equity issued is lower (Shleifer and Wolfenzon 2002, La Porta et al. 2002). Securities laws, in so far as they reduce the cost of contracting and resolving disputes, can encourage equity financing of firms and stock market development. The Dutch example also suggests that solving the promoter's problem is important not only for equity markets but for debt markets as well.

\section{The Variables.}

Our data on the regulation of the promoter's problem is based on answers to a questionnaire 
by attorneys in the sample of 49 countries with the largest stock market capitalization in 1993 (La

Porta et al. 1998). We invited one attorney from each country to answer the questionnaire describing the securities laws (including actual laws, statues, regulations, binding judicial precedents, and any other rule with force of law) applicable to an offering of shares listed in the country's largest stock exchange in December of 2000. $\quad$ All 49 authors returned answered questionnaires, and subsequently confirmed the validity of their answers as we recorded them. All the variables derived from the questionnaires and other sources are defined in Table I.

\section{Private Enforcement}

As James Landis, the principal author of U.S. securities laws, recognized, making private recovery of investors' losses easy was essential to harnessing the incentives of market participants to enforce securities laws (Landis 1938, Seligman, 1995). Efficiency considerations suggest that the lowest cost provider of information about a security should collect and present this information, and be held accountable if he omits or misleads. In the Grossman-Hart model (1980), for example, the lowest cost providers are not the investors, but the issuers, the distributors, and the accountants. ${ }^{6}$ An efficient system would provide them with incentives to collect and present information to investors, and hold them liable if they do not. In securities laws, this strategy generally takes the form of disclosure requirements and liability rules that make it cheaper for investors to recover

\footnotetext{
${ }^{5} \mathrm{We}$ first approached authors who had published country reports on securities laws in publications such as International Securities Regulation and International Securities Laws. When countries were not covered in such publications or authors declined our invitation, we searched the Martindale Law Directory to identify leading law firms practicing in the area of securities laws and invited them to answer the questionnaire. The respondents received a questionnaire designed by the authors with the help of practicing lawyers in Argentina, Japan, and the United States.

${ }^{6}$ Two other features of initial public offerings make "buyer-beware" rules unattractive. First, the scope for fraud is very large. Second, the damages resulting from investing in reliance of a defective prospectus are much easier to calculate than those that result from, for example, the use of a defective appliance.
} 
damages when information is wrong or omitted -- the two features we try to capture empirically.

We collect six proxies for the strength of specific disclosure requirements pertaining to the promoter's problem. The first and most basic question is whether promoters can issue securities without delivering a prospectus describing them to potential investors in advance. Since every country requires a prospectus before securities are sold and listed, the operational word here is “delivering." In some countries, it is possible to sell securities after a prospectus is deposited at the company, or with the Supervisor, without delivering it to investors. Delivering a prospectus to potential investors is an affirmative step in making disclosures to them. In addition, we keep track of affirmative disclosure requirement in the following five areas: (1) insiders' compensation; (2) ownership by large shareholders; (3) inside ownership; (4) contracts outside the normal course of business; and (5) transactions with related parties. We calculate a sub-index of "disclosure requirements" as the average of the preceding six proxies.

In addition to specific disclosure requirements, nearly every country has a residual disclosure requirement that the prospectus includes all material information necessary to assess the value of the securities being offered. When bad news hit after security issuance, the question becomes whether this information was known or knowable to the issuer, the distributor, and/or the accountant and omitted from the prospectus. As the Dutch example illustrates, the standard of proof in the cases of such omission is central to private enforcement of securities laws. The centrality of the liability regime has largely been lost in the recent legal literature, which has focused instead on the importance of mandatory disclosure. Here we focus explicitly on the liability regime. ${ }^{7}$

\footnotetext{
7 Some have asked us to examine whether the availability of class action suits is associated with the development of securities markets. A dummy equal to one if class actions are available in a prospectus liability case is an insignificant predictor of the development of securities markets.
} 
There are basically four liability regimes. In the "base" case, the standard of liability is the same as in torts, namely negligence: the plaintiff must show that the issuer, the distributor, or the accountant was negligent in omitting information from the prospectus. The tort standard also requires that investors prove that they relied on the prospectus to invest (reliance) or that their losses were caused by the misleading information in the prospectus (causality). Some countries make it even harder for the plaintiffs, who must show that the defendants were grossly negligent (e.g., "drunk") or intentioned in omitting the information that later comes to light. The burden of proof is less demanding than tort in countries where investors must prove reliance or causality or both, but not negligence. Finally, the burden of the proof is lowest where plaintiffs only need to show that the information in the prospectus was misleading (but not reliance or causality). The defendants are either strictly liable, or they must themselves show that they exercised due diligence in preparing the prospectus. This shift in the burden of proof from plaintiffs to defendants can, in principle, significantly reduce the cost to the former of establishing liability.

In our empirical analysis, we code the burden of proof in a prospectus liability case against directors, distributors, and accountants and compute a "burden-of-proof" sub-index. Finally, we combine the sub-indices of disclosure and burden of proof into a "private-enforcement" index.

\section{Public Enforcement}

In the context of a securities markets, a public enforcer can be a Securities Commission, a Central Bank, or some other supervisory body. For concreteness, we call the main government agency or official authority in charge of supervising securities markets the Supervisor. We focus on four broad aspects of public enforcement. 
The first aspect covers the basic attributes of the Supervisor, which we capture with four variables. First, an effective Supervisor may need to be insulated from interference by the Executive both to facilitate recruiting professional staff and to prevent political interference on behalf of influential issuers. To measure the Supervisor's independence, we keep track of whether its key members are appointed through a system of checks-and-balances or unilaterally by the Executive. Second, and relatedly, the independence of the Supervisor may be enhanced when its key members may only be dismissed after due process rather than at the will of the appointing authority. Third, an effective Supervisor may need to be focused on securities markets, rather than on both these markets and banking, so that his success is more closely tied to that of the securities market. Accordingly, we measure whether the Supervisor's mandate covers securities markets alone. Fourth, it may be important that the power to regulate securities markets be delegated to the Supervisor, rather than remain with the legislature or the Ministry of Finance (Spiller and Ferejohn 1992). We measure whether the Supervisor has the power to regulate primary offerings and/or listing rules on stock exchanges. We combine these four variables into a sub-index of "Supervisor attributes".

The second aspect covers the investigative powers of the Supervisor. Unless the issuer, the distributor, and the auditor are strictly liable for all false and misleading statements in the prospectus(which never happens), the question arises as to why the information revealed to investors was inaccurate. Did the issuer, distributor, or auditor have the information? If not, could they have had it? At what cost? Did the issuer hide the information from the distributor or the auditor? Answering these questions is costly, especially for private plaintiffs. A Supervisor can be empowered to command documents from issuers, distributors, or accountants, and to subpoena 
testimony of witnesses. Such powers can in principle enable the Supervisor to ascertain the reasons for inaccuracy which can then - as a public good - become the basis for sanctions, or for criminal, or civil litigation. We summarize the powers of the Supervisor to subpoena documents and witnesses by forming a sub-index of "Investigative powers".

The third aspect - perhaps most directly intended to substitute for the weakness of private enforcement - covers non-criminal sanctions for violations of securities laws. These sanctions may involve ordering the directors of a public firm to rectify non-compliance with disclosure requirements, to institute changes recommended by outside reviewers, and/or to compensate investors for their losses. Such sanctions could be imposed separately on issuers, distributors, and accountants, and we keep track of each category. We then average the scores for the sanctions against the various parties to create a sub-index of "orders".

Finally, the fourth aspect covers criminal sanctions for violations of securities laws. We keep track of whether criminal sanctions are applicable, to whom they apply, and what conduct invokes them. We average the scores for criminal sanctions against directors, distributors, and accountant to obtain a sub-index of "criminal sanctions". These variables are of special interest since a popular sentiment in the current discussions of securities laws sees criminal sanctions as essential to enforcing good practices. We average the preceding four sub-indexes for public enforcement to form the index of "public enforcement".

\section{Other Variables}

We are interested in understanding the effects of the various provisions in securities laws on financial development. We use seven proxies for the development of securities markets in different 
countries. The first variable is the ratio of stock market capitalization to GDP scaled by the fraction of stock market held by outside investors. (The results are qualitatively similar for the unadjusted ratio of market capitalization to GDP.) The second variable is the (logarithm of the) number of domestic publicly-traded firms in each country relative to its population. The third variable is the value of initial public offerings in each country relative to its GDP. All three variables are five-year averages of yearly data for the period 1996-2000. Theoretically, the first of these three measures is the most attractive, since in theory better investor protection is associated with both a higher number of listed firms and higher valuation of capital (Shleifer and Wolfenzon 2002). Except for some differences in scaling and timing, these three variables were used in La Porta et al. (1997) to study the consequences of investor protection through corporate law on stock market development.

The fourth variable is a qualitative assessment of the ability of new and medium-sized firms to raise equity in the stock market based on a survey of business executives by the Global Competitiveness Report (1999). The fifth variable is the (median) premium paid for control in corporate control transactions. In several theoretical models, this variable has been interpreted as a measure of private benefits of control, which are higher in countries with weaker investor protection (Grossman and Hart 1988, Dyck and Zingales 2003, Nenova 2003). The sixth variable is a proxy for the quality of accounting information actually reported by firms, as measured by an index of earnings' manipulation (Leuz, Nanda, and Wysocki 2002). Finally, the seventh variable is a proxy for ownership concentration among the largest firms in the country. ${ }^{8}$ Both theory (Shleifer and Wolfenzon 2002) and prior empirical work (La Porta, Lopez-de-Silanes, and Shleifer 1999) suggest that ownership concentration is lower in countries with better investor protection.

\footnotetext{
${ }^{8} \mathrm{We}$ also tried stock market turnover as a measure of liquidity. The results are qualitatively similar to those for the variables used in the paper.
} 
To isolate the effect of securities laws on financial markets, we control for several factors identified by previous research. The first of these is the level of economic development, which we measure as the (logarithm of) per capita GDP. Economic development is often associated with capital deepening. In addition, richer countries might have higher quality institutions in general, including better quality of law enforcement, which could be associated with better financial development regardless of the content of the laws (North 1981, La Porta et al. 1999). To further address this issue, we use the measure of the efficiency of the judiciary from the International Country Risk Guide as an additional control.

La Porta et al. $(1997,1998)$ present evidence that measures of investor protection derived from corporate law are associated with stock market development. This evidence raises the question of which laws, if any, make a difference. Accordingly, in all our regressions, we include the antidirectors rights index of the protection afforded to shareholders through statutory corporate law as an additional control.

As in many other studies in this area, the causal effect of securities laws on financial development cannot be established with certainty. Following La Porta et al. (1997, 1998), we use the legal origin of commercial laws as an instrument. The commercial laws of most countries originate in one of four legal families: English (common) law, French civil law, German civil law, and Scandinavian law, which have spread throughout the world through conquest, colonization, and occasionally voluntary transplantation. Common and civil law are intimately connected to the distinction between public and private enforcement that we are interested in testing. England developed a common law tradition, characterized by independent judges and juries, relatively weaker reliance on statutes, and the preference for contracts and private litigation as a means of 
dealing with social harms. France, in contrast, developed a civil law tradition, characterized by stateemployed judges, great reliance on legal and procedural codes, and a preference for state regulation over private litigation. This makes legal origin a suitable instrument for the stance of the law regarding public and private enforcement.

Overview of the Data

Table II presents our data on securities laws. Countries are arranged by legal origin, and we report means by legal origin as well as tests of the differences in these means. Common and civil law countries differ significantly in our measures of both private and public enforcement. In the private enforcement area, common law countries both have more extensive mandatory disclosure requirements, and make it easier for investors to recover damages. In the public enforcement area, these differences are smaller for Supervisor attributes (Supervisors in German and Scandinavian legal origin countries are weaker than in the other two groups), and greater for investigative powers, orders, and criminal sanctions. Compared to civil law countries, Supervisors in common law countries have more extensive investigative powers and both criminal and non-criminal sanctions are more severe. In the next section, we examine which dimensions of the security law matter for financial development, and investigate the roles of securities and corporate law as determinants of financial development.

\section{Securities laws and financial development.}

Table III presents the results of regressions of stock market capitalization to GDP ratio on the anti-director rights index, efficiency of the judiciary, logarithm of GDP per capita, and each of 
our individual sub-indices of investor protection through the securities law. Both higher per capita GDP and efficiency of the judiciary are associated with larger stock markets, and these effects are quantitatively large. Perhaps most interestingly, both disclosure requirements and burden of the proof are positively correlated with larger stock markets. In contrast, none of our sub-indices of public enforcement enters significantly. Finally, the index of anti-director rights is significant only when combined with measures of public enforcement and drops out from the regressions that include proxies for private enforcement. To put the results on private enforcement in perspective, in our sample, the external-market-capitalization-to-GDP ratio ranges from 0.002 in Uruguay to 1.44 in Switzerland. The estimated coefficient suggests that improving disclosure requirements by two standard deviations - roughly the distance from Denmark or Norway to the U.S. - is associated with an increase in the market-capitalization-to-GDP ratio of 0.27. Similarly, the estimated coefficient suggests that lowering the burden of the proof by two standard deviations - the distance from Ireland to the U.S. -- is associated with an increase in the market-capitalization-to-GDP ratio of 0.20 .

We do not report the results for other measures of stock market development and securities law sub-indices because they are similar to those in Table III. The results on private enforcement are consistently strong. Specifically, both broader mandatory disclosure requirements and a lighter burden of establishing the liability of issuers, distributors, and accountants are associated with more developed stock markets for all dependent variables except for earnings manipulation. With respect to public enforcement, the results are much weaker. First, the Supervisor's characteristics (i.e., independence, focus, and power to make rules) do not matter for any of the outcome variables. Second, the Supervisor's investigative power is only associated with more domestic firms. Third, the Supervisor's power to issue orders is only associated with more IPOs and less earnings 
manipulation (and weakly $-\mathrm{t}$-stat of $1.65-$ with more domestic firms). Fourth, criminal sanctions only matter for IPOs. Criminal deterrence may be ineffective because proving criminal intent of issuers, distributors, or accountants in omitting information from the prospectus is difficult.

These results suggest a preliminary view of what works, and what does not, in security laws. Public enforcement plays, at best, a modest role in the development of stock markets. Specifically, there is no evidence that such factors as Supervisor's independence or focus work. Both the Supervisor's investigative powers and the strength of both criminal and non-criminal sanctions only matter for a narrow set of outcomes. In contrast, the development of stock markets is strongly associated with measures of private enforcement such as extensive disclosure requirements and a relatively low burden of proof on investors seeking to recover damages resulting from omissions of material information from the prospectus.

In the remainder of this section, we explore these preliminary findings from a range of perspectives. To reduce the number of regressions, we focus on aggregate indices of public and private enforcement. Since both of our private enforcement sub-indices work reasonably well, aggregating them into an index is straightforward. Combining the sub-indices of public enforcement may increase its importance of public enforcement if its various dimensions are substitutes.

Table IV presents the results of regressing financial development on private enforcement (Panel A), public enforcement (Panel B), and on both of them (Panel C). To interpret the results on Table IV, note that, when securities laws are excluded from the regression, stronger anti-director rights are associated with better stock market development for all dependent variables except the index of access to equity (results not reported). Panel A shows, however, that private enforcement knocks out anti-director rights as a significant predictor of market development. Instead, private 
enforcement is associated with more developed stock markets for all seven dependent variables. The estimated coefficients predict that a two-standard deviation increase in private enforcement is (roughly the distance from Ireland to the U.S.) is associated with an increase of 0.30 in the externalmarket-to-GDP ratio, a 55\% rise in listed firms per capita, a 2.34 increase in the IPO-to-GDP ratio, a 12 percentage point drop in the block premia, an improvement of 1 point in the access-to-equity index, a decrease of 5.25 points in the earnings manipulation index, and a 10 percentage point drop in ownership concentration.

The results for public enforcement in Panel B are less consistent. For the number of listed domestic firms and IPOs, it is public enforcement, but not anti-director rights, that matters, and the economic effect of public enforcement in these regressions is large. A two-standard deviation increase in public enforcement (roughly from Sweden to the U.S. ) is associated with a $42 \%$ increase in listed firms per capita and adds 1.6 to the IPO-to-GDP ratio. In contrast, anti-director rights, but not public enforcement, typically matters for the other measures of stock market development (with the exception of earnings manipulation for which neither variable matters).

Finally, Panel C presents the results of a horse race between our proxies for private and public enforcement. The key result is that private enforcement is significant in all but one of the regressions (earnings manipulation). In contrast, public enforcement is never significant when combined with private enforcement (i.e., private enforcement knocks out public enforcement from the regressions for domestic firms and IPOs). ${ }^{9}$ Finally, consistent with Panel A, the anti-director rights index plays a minor role and is only significant in the regression for ownership concentration.

The empirical result that investor protections through securities laws dwarf those from

\footnotetext{
${ }^{9}$ The correlation between public- and private-enforcement is 0.43 (see Appendix B). The results are qualitatively similar if we run horse-race regressions using each of the components of public enforcement rather than the index.
} 
corporate law in encouraging equity finance must be interpreted with caution. Corporate law and securities laws may rely on similar rules (e.g., regarding the burden-of-the-proof in civil cases). For example, the U.S. system of mandatory disclosure evolved out of common law principles applicable to agents dealing adversely with their principals (Mahoney 1995). In fact, the correlation coefficient between the anti-director index and private enforcement is 0.57 (see Appendix B).

\section{Robustness}

In this section, we address three issues of robustness. First, is the weakness of our results on public enforcement due to measurement problems? Second, what omitted variables may explain the strength of our results on private enforcement? Third, is private enforcement endogenous?

Public enforcement may only be effective in countries with efficient government bureaucracies. To address this concern we have rerun our regressions for the sub-sample of countries with per capita GDP above the median. ${ }^{10}$ We find no consistent evidence that public enforcement is correlated with larger securities markets in these countries. A related concern is that public enforcement may be ineffective if the Supervisor lacks adequate resources. To address this concern, we have collected data on the number of employees that work for the Supervisor. We find that the (log of ) the number of employees is insignificant in our regressions. To get at the interaction between public enforcement and the resources of the Supervisor, we break the sample according to whether the number of employees working for the Supervisor is above or below the sample median and run separate regressions for both groups of countries. Public enforcement is statistically significant only for IPOs and earnings manipulation in countries with well-staffed regulators (and government.

${ }^{10}$ The results are qualitatively similar if we break the sample using survey measures of the quality of 
for domestic firms in countries with poorly-staffed ones).

It might be argued that financial markets are small where the state is large. For example, few firms may be publicly-traded in countries where the state owns most of the capital. Omitted variable bias may account for the strength of our results if private enforcement is negatively correlated with the role of the state in the economy. To address this concern, we have included two measures of the role of the state in the economy in our regressions: (1) the fraction of the capital stock in the hands of state-owned companies from La Porta et al. (1999); and (2) the fraction of the banking assets controlled by government-owned banks from La Porta, Lopez-de-Silanes, and Shleifer (2002). Our results on securities laws remain qualitatively unchanged. Another omitted variable story holds that countries with large capital markets may come to rely on private enforcement because their institutions are more responsive to the interests of small investors. However, measures of democracy and political rights are uncorrelated with private enforcement (and public enforcement). Moreover, such measures are not significant predictors of financial development in our regressions.

Finally, it is possible that governments adopt better securities laws in countries with buoyant financial markets. For example, countries with large financial markets may adopt good regulations because there are fixed costs of doing so. This argument is undermined by the systematic differences in investor protection across legal origins. Reverse causality is also undermined by the fact that the dimensions of the law that are expensive to implement - for example, having an independent and focused regulator - do not seem to matter. On the contrary, what matters is legal rules that are cheap rather than expensive to introduce. A second reverse causality argument holds that regulators swarm toward large securities markets, because there are bigger rents to secure from regulating them. This argument is also undermined by the fact that it is precisely the regulations that render the regulators 
unimportant, namely those that standardize private contracting and litigation, that have the tightest association with stock market development.

We can partially address endogeneity problems using instrumental variables. In practice, legal origin is the only suitable instrument. As a result, we cannot treat both securities and corporate law as endogenous. ${ }^{11}$ To get around this problem, we replace private enforcement and anti-director rights with the principal component of these two variables, which we call investor protection. ${ }^{12}$ This principal component accounts for $79 \%$ of the variation in private enforcement and anti-director rights. Table $\mathrm{V}$ presents the two stage least squares results using English legal origin as an instrument. ${ }^{13}$ Investor protection is statistically significant for all seven proxies of stock market development. These results should partially mitigate endogeneity concerns.

\section{Conclusion.}

In the introduction, we described the three hypotheses concerning the effect of securities laws on stock market development. Our findings provide clear evidence bearing on these hypotheses.

First, the answer to the question of whether "law matters" is a definite yes. Our findings corroborate the earlier research that shows that investor protections provided in corporate law matter for securities markets, by showing that investor protections provided by the securities law also

11 In addition to legal origin, we tried proxies for culture (e.g., religious affiliation) and endowments (e.g., latitude and ethno-linguistic fractionalization) as instruments. However, the predicted values of private enforcement and anti-director rights are highly collinear.

${ }^{12}$ Similar instrumental variable results obtain if, instead of the principal component, we use the average or the product of anti-director rights and private enforcement.

13 The first-stage $F$ statistic is 31.45 , which suggests that there is no problem of weak instruments (Staiger and Stock 1997). The OLS and IV estimated coefficients are very similar in magnitude. 
matter - perhaps even more so.

Second, our findings suggest that securities laws matter because they reduce the costs of private contracting and litigation rather than provide for public regulatory enforcement. When we try to understand specifically what works in securities laws, we find that several aspects of public enforcement, such as having an independent and/or focused regulator or criminal sanctions, do not matter, and others matter in only some regressions. In contrast, both extensive disclosure requirements and a simple procedure to facilitate investor recovery of losses are associated with larger stock markets.

At the more general level, these results illustrate the theory of optimal institutions in Djankov et al. (2003), which maintains that optimal intervention is shaped by the tradeoff between the costs of market and government failure. For the case of securities markets, our evidence suggests that the efficient institutional choice takes the form of private enforcement of public rules, which encourages private recovery of damages by investors harmed by promoters. Other markets may call for less government intervention, still others for heavier regulation. Generally speaking, it will take an empirical approach, such as that undertaken here, to understand what institutions are efficient in a specific environment. In this respect, this analysis confirms Coase's (1960) view that efficient institutional arrangements vary across activities, and minimize total transaction costs, including both those of market and government failure. 


\section{References}

Barth, James, Gerard Caprio, and Ross Levine, 2003, "Bank Supervision and Regulation: What Works Best?," Journal of Financial Intermediation, forthcoming.

Becker, Gary, 1968, “Crime and Punishment: An Economic Approach,” Journal of Political Economy 76, 169-217.

Beny, Laura, 2002, “A comparative empirical investigation of agency and market theories of insider trading," Harvard University mimeo.

Bergman, Nittai and Daniel Nicolaievsky, 2002, "Investor Protection and the Coasian View," Harvard University mimeo.

Black, Bernard, 2001, "The Legal and Institutional Preconditions for Strong Securities Markets," UCLA Law Review 48, 781-858.

Black, Bernard, and Reinier Kraakman, 1996, “A Self-Enforcing Model of Corporate Law," Harvard Law Review 109, 1911-1981.

Coase, Ronald, 1960, “The Problem of Social Cost," Journal of Law and Economics 3, 1-44.

Coffee, John, 1984, "Market Failure and the Economic Case for a Mandatory Disclosure System," Virginia Law Review 70, 717-753.

Coffee, John, 1989, “The Mandatory/Enabling Balance in Corporate Law: An Essay on the Judicial Role," Columbia Law Review 89, 1618-1691.

Coffee, John, 2002, “The Rise of Dispersed Ownership: The Roles of Law and the State in the Separation of Ownership Control," Yale Law Review 111.

Dechow, Patricia, Richard Sloan, and Amy Sweeney, "Causes and Consequences of Earnings Manipulations: An Analysis of Firms Subject to Enforcement Actions by the SEC," 
Contemporary Accounting Research 13, 1-36.

Djankov, Simeon, Edward Glaeser, Rafael La Porta, Florencio Lopez-de-Silanes, and Andrei Shleifer, 2003, "The New Comparative Economics," Journal of Comparative Economics, forthcoming.

Dyck, Alexander and Luigi Zingales, 2003, "Private Benefits of Control: An International Comparison," Journal of Finance, forthcoming.

Easterbrook, Frank and Daniel Fischel, 1984, "Mandatory Disclosure and the Protection of Investors," Virginia Law Review 70, 669-715.

Fox, Merritt, 1999, "Retaining mandatory disclosure: Why issuer choice is not investor empowerment," Virginia Law Review 85, 1335-419.

Friend, Irwin and Edward Herman, 1964, “The S.E.C. Through a Glass Darkly,” Journal of Business $37,382-405$.

Glaeser, Edward, Simon Johnson and Andrei Shleifer, 2001, “Coase versus the Coasians," Quarterly Journal of Economics 116, 853-899.

Glaeser, Edward and Andrei Shleifer, 2001, "A Reason for Quantity Regulation," American Economic Review Papers and Proceedings 91, 431-435.

Glaeser, Edward and Andrei Shleifer, 2002, “Legal Origins,” Quarterly Journal of Economics 117, 1193-1230.

Glaeser, Edward and Andrei Shleifer, 2003, "The Rise of the Regulatory State," Journal of Economic Literature 41, 401-425.

Grossman, Sanford and Oliver Hart, 1980, "Disclosure Laws and Takeover Bids," Journal of Finance 35, 323-334. 
Grossman, Sanford and Oliver Hart, 1988, "One share-one vote and the market for corporate control," Journal of Financial Economics 20, 175-202.

Hartland-Peel, Christopher, 1996, African Equities: A Guide to Markets and Companies, London, Euromoney Publications.

Hay, Jonathan and Andrei Shleifer, 1998, "Private Enforcement of Public Laws: A Theory of Legal Reform," American Economic Review Papers and Proceedings 88, 398-403.

Hay, Jonathan, Andrei Shleifer and Robert Vishny, 1996, "Toward a Theory of Legal Reform," European Economic Review 40, 559-567.

International Finance Corporation, 2001, Emerging Markets Data Base, located online at: http://www.ifc.org/EMDB/EMDBHOME.HTM.

La Porta, Rafael, Florencio Lopez-de-Silanes, and Andrei Shleifer, 1999, “Corporate Ownership Around the World," Journal of Finance 54, 471-517.

La Porta, Rafael, Florencio Lopez-de-Silanes, and Andrei Shleifer, 2002, “Government Ownership of Banks," Journal of Finance 57, 265-301.

La Porta, Rafael, Florencio Lopez-de-Silanes, Andrei Shleifer, and Robert Vishny, 1997, “Legal Determinants of External Finance,” Journal of Finance 52, 1131-1150.

La Porta, Rafael, Florencio Lopez-de-Silanes, Andrei Shleifer, and Robert Vishny, 1998, “Law and Finance," Journal of Political Economy 106, 1113-1155.

La Porta, Rafael, Florencio Lopez-de-Silanes, Andrei Shleifer, and Robert Vishny, 1999, “The Quality of Government," Journal of Law, Economics and Organization 15, 222-279.

La Porta, Rafael, Florencio Lopez-de-Silanes, Andrei Shleifer, and Robert Vishny, 2002, "Investor Protection and Corporate Valuation," Journal of Finance 57, 1147-1170. 
Landis, James, 1938, The Administrative Process, (New Haven, CT: Yale University Press).

Leuz, Christian, Dhananjay Nanda and Peter Wysocki, 2002, Earnings Management and Investor Protection: An International Comparison, Journal of Financial Economics, forthcoming. Macey, Jonathan, 1994, “Administrative Agency Obsolescence and Interest Group Formation: A Case Study of the SEC at Sixty," Cardozo Law Review 15, 909-949.

Mahoney, Paul, 1995, "Mandatory Disclosure as a Solution to Agency Problems," University of Chicago Law Review 62, 1047-1112.

Nenova, Tatiana, 2003, “The Value of Corporate Voting Rights and Control: A Cross-country Analysis," Journal of Financial Economics 68, 325-351.

North, Douglass, 1981, Structure and Change in Economic History, (New York: Norton).

Pistor, Katharina and Chenggang Xu, 2002, "Law Enforcement under Incomplete Law: Theory and Evidence from Financial Market Regulation," Columbia Law School mimeo.

Polinsky, Mitchell and Steven Shavell, 2000, “The Economic Theory of Public Enforcement of Law," Journal of Economic Literature 38, 45-76.

Political Risk Services, 1996, International Country Risk Guide (Political Risk Services, East Syracuse, NY).

Reese, William, and Michael Weisbach, 2002, "Protection of minority shareholder interests, crosslistings in the United States, and subsequent equity offerings," Journal of Financial Economics 66:1, 65-104.

Seligman, Joel, 1995, The transformation of Wall Street : a history of the Securities and Exchange Commission and modern corporate finance, (Boston : Northeastern University Press).

Shleifer, Andrei and Daniel Wolfenzon, 2002, "Investor Protection and Equity Markets," Journal 
of Financial Economics 66:1, 3-27.

Schwab, Klaus et al., eds., World Economic Forum, 1999, The Global Competitiveness Report 1999, Oxford University Press, New York.

Simon, Carol, 1989, "The Effect of the 1933 Securities Act on Investor Information and the Performance of New Issues," American Economic Review 79, 295-318.

Spiller, Pablo and John Ferejohn, 1992, "The Economics and Politics of Administrative Law and Procedures: An Introduction," Journal of Law, Economics and Organization 8, 1-7.

Staiger, Douglas and James Stock, 1997, "Instrumental Variables Regression with Weak Instruments," Econometrica 65(3), 557-86.

Stigler, George, 1964, "Public Regulation of the Securities Market," Journal of Business 37, 117142.

Stulz, René, 1999, "Globalization of Equity Markets and the Cost of Capital," Journal of Applied Corporate Finance 12, 8-25.

Teoh, Siew Hong, Ivo Welch, and T.J. Wong, 1998, "Earnings Management and the Long-Run Market Performance of Initial Public Offerings," The Journal of Finance 53:6, 1395-1974. Velthuyse, Heleen and Francine Schlingmann, 1995, "Prospectus Liability in The Netherlands," Journal of International Business Law, 229-236.

World Bank, 2001, World Development Indicators 2001, [CD-ROM] Washington, DC. World Bank. 


\section{Table I - Description of the Variables}

This table describes the variables in the paper. The Supervisor is the main government agency in charge of supervising stock exchanges. The Issuer is a domestic corporation that raises capital through an initial public offering of common shares. The newly-issued shares will be listed on the country's largest stock exchange. The Distributor advises the Issuer on the preparation of the prospectus and assists in marketing the securities but does not authorize (or sign) the prospectus unless required by law. The Accountant audits the financial statements and documents that accompany the prospectus. Unless otherwise specified, the source for the variables is the questionnaire of law firms and the laws of each country. The edited answers to the questionnaire are posted at http://post.economics.harvard.edu/faculty/shleifer/papers/securities_documentation.pdf.

\begin{tabular}{ll}
\hline Variable & Description \\
\hline
\end{tabular}

\section{I.1 Disclosure requirements}

Prospectus Equals one if the law prohibits selling securities that are going to be listed on the largest stock exchange of the country without delivering a prospectus to potential investors; equals zero otherwise.

Compensation An index of prospectus disclosure requirements regarding the compensation of directors and key officers. Equals one if the law or the listing rules require that the compensation of each director and key officer be reported in the prospectus of a newly-listed firm; equals one-half if only the aggregate compensation of directors and key officers must be reported in the prospectus of a newly-listed firm; equals zero when there is no requirement to disclose the compensation of directors and key officers in the prospectus for a newly-listed firm.

Shareholders An index of disclosure requirements regarding the Issuer's equity ownership structure. Equals one if the law or the listing rules require disclosing the name and ownership stake of each shareholder who, directly or indirectly, controls ten percent or more of the Issuer's voting securities; equals one-half if reporting requirements for the Issuer's 10\% shareholders do not include indirect ownership or if only their aggregate ownership needs to be disclosed; equals zero when the law does not require disclosing the name and ownership stake of the Issuer's $10 \%$ shareholders. No distinction is drawn between large-shareholder reporting requirements imposed on firms and those imposed on large shareholders themselves.

Inside ownership An index of prospectus disclosure requirements regarding the equity ownership of the Issuer's shares by its directors and key officers. Equals one if the law or the listing rules require that the ownership of the Issuer's shares by each of its director and key officers be disclosed in the prospectus; equals one-half if only the aggregate number of the Issuer's shares owned by its directors and key officers must be disclosed in the prospectus; equals zero when the ownership of Issuer's shares by its directors and key officers need not be disclosed in the prospectus.

Irregular

contracts

An index of prospectus disclosure requirements regarding the Issuer's contracts outside the ordinary course of business. Equals one if the law or the listing rules require that the terms of material contracts made by the Issuer outside the ordinary course of its business be disclosed in the prospectus; equals one-half if the terms of only some material contracts made outside the ordinary course of business must be disclosed; equals zero otherwise.

Transactions An index of the prospectus disclosure requirements regarding transaction between the Issuer and its directors, officers, and/or large shareholders (i.e., "related parties"). Equals one if the law or the listing rules require that all transactions in which related parties have, or will have, an interest be disclosed in the prospectus; equals one-half if only some transactions between the Issuer and related parties must be disclosed in the prospectus; equals zero if transactions between the Issuer and related parties need not be disclosed in the prospectus.

Disclosure index The index of disclosure equals the arithmetic mean of: (1) Prospect; (2) Compensation; (3) Shareholders; (4) Inside ownership; (5) Contracts Irregular; (6) and Transactions.

\section{I.2 Burden of Proof}

Burden director Index of the procedural difficulty in recovering losses from the Issuer's directors in a civil liability case for losses due to misleading statements in the prospectus. Equals one when investors are only required to prove that the prospectus contains a misleading statement. Equals two-thirds when investors must also prove that they relied on the prospectus and/or that their loss was caused by the misleading statement. Equals one-third when investors prove that the director acted with negligence and that they either relied on the prospectus or that their loss was caused by the misleading statement or both. Equals zero if restitution from directors is unavailable or the liability standard is intent or gross negligence. 
Burden distributor

Burden accountant

Burden of proof index

Appointment

Tenure

Focus

Rules

Supervisor characteristics index

\section{Document}

Witness

Investigative powers index
Index of the procedural difficulty in recovering losses from the Distributor in a civil liability case for losses due to misleading statements in the prospectus. Equals one when investors are only required to prove that the prospectus contains a misleading statement. Equals two-thirds when investors must also prove that they relied on the prospectus and/or that their loss was caused by the misleading statement. Equals one-third when investors prove that the Distributor acted with negligence and that they either relied on the prospectus or that their loss was caused by the misleading statement or both. Equals zero if restitution from the Distributor is unavailable or the liability standard is intent or gross negligence.

Index of the procedural difficulty in recovering losses from the Accountant in a civil liability case for losses due to misleading statements in the audited financial information accompanying the prospectus. Equals one when investors are only required to prove that the audited financial information accompanying the prospectus contains a misleading statement. Equals two-thirds when investors must also prove that they relied on the prospectus and/or that their loss was caused by the misleading accounting information. Equals one-third when investors prove that the Accountant acted with negligence and that they either relied on the prospectus or that their loss was caused by the misleading statement or both. Equals zero if restitution from the Accountant is unavailable or the liability standard is intent or gross negligence.

The index of burden of proof equals the arithmetic mean of: (1) Burden director; (2) Burden distributor; and (3) Burden accountant.

\section{II.1 Characteristics of the Supervisor of Securities Markets}

Equals one if a majority of the members of the Supervisor are unilaterally appointed by the Executive branch of government; equals zero otherwise.

Equals one if members of the Supervisor cannot be dismissed at the will of the appointing authority; equals zero otherwise.

Equals one if separate government agencies or official authorities are in charge of supervising commercial banks and stock exchanges; equals zero otherwise.

Equals one if the Supervisor can generally issue regulations regarding primary offerings and/or listing rules on stock exchanges without prior approval of other governmental authorities. Equals one-half if the Supervisor can generally issue regulations regarding primary offerings and/or listing rules on stock exchanges only with the prior approval of other governmental authorities. Equals zero otherwise.

The index of characteristics of the Supervisor equals the arithmetic mean of: (1) Appointment; (2) Tenure; (3) Focus; and (4) Rules.

\section{II.2 Investigative Powers of the Supervisor of Securities Markets}

An index of the power of the Supervisor to command documents when investigating a violation of securities laws. Equals one if the Supervisor can generally issue an administrative order commanding all persons to turn over documents; equals one-half if the Supervisor can generally issue an administrative order commanding publiclytraded corporations and/or their directors to turn over documents; equals zero otherwise.

An index of the power of the Supervisor to subpoena the testimony of witnesses when investigating a violation of securities laws. Equals one if the Supervisor can generally subpoena all persons to give testimony; equals one-half if the Supervisor can generally subpoena the directors of publicly-traded corporations to give testimony; equals zero otherwise.

The index of investigative powers equals the arithmetic mean of: (1) Document; and (2) Witness. 
Orders issuer

Orders distributor

Orders accountant

Orders index

Criminal director/officer

Criminal distributor

Criminal accountant

Criminal index

Private enforcement index

Public enforcement index
An index aggregating stop and do orders that may be directed at the Issuer in case of a defective prospectus. The index is formed by averaging the sub-indexes of orders to stop and to do. The sub-index of orders to stop equals one if the Issuer may be ordered to refrain from a broad range of actions; equals one-half if the Issuer may only be ordered to desist from limited actions; equals zero otherwise. The sub-index of orders to do equals one if the Issuer may be ordered to perform a broad range of actions to rectify the violation; equals one-half if the Issuer may only be ordered to perform limited actions; equals zero otherwise. We disregard orders that may be issued by Courts at the request of a private party in a civil lawsuit.

An index aggregating stop and do orders that may be directed at the Distributor in case of a defective prospectus. The index is formed by averaging the sub-indexes of orders to stop and to do. The sub-index of orders to stop equals one if the Distributor may be ordered to refrain from a broad range of actions; equals one-half if the Distributor may only be ordered to desist from limited actions; equals zero otherwise. The sub-index of orders to do equals one if the Distributor may be ordered to perform a broad range of actions to rectify the violation; equals one-half if the Distributor may only be ordered to perform limited actions; equals zero otherwise. We disregard orders that may be issued by Courts at the request of a private party in a civil lawsuit.

An index aggregating stop and do orders that may be directed at the Accountant in case of a defective prospectus. The index is formed by averaging the sub-indexes of orders to stop and to do. The sub-index of orders to stop equals one if the Accountant may be ordered to refrain from a broad range of actions; equals one-half if the Accountant may only be ordered to desist from limited actions; equals zero otherwise. The sub-index of orders to do equals one if the Accountant may be ordered to perform a broad range of actions to rectify the violation; equals one-half if the Accountant may only be ordered to perform limited actions; equals zero otherwise. We disregard orders that may be issued by Courts at the request of a private party in a civil lawsuit.

The index of orders equals the arithmetic mean of: (1) Orders issuer; (2) Orders distributor; and (3) Orders accountant.

An index of criminal sanctions applicable to the Issuer's directors and key officers when the prospectus omits material information. We create separate sub-indexes for directors and key officers and average their scores. The sub-index for directors equals zero when directors cannot be held criminally liable when the prospectus is misleading. Equals one-half if directors can be held criminally liable when aware that the prospectus is misleading. Equals one if directors can also be held criminally liable when negligently unaware that the prospectus is misleading. The sub-index for key officers is constructed analogously.

An index of criminal sanctions applicable to the Distributor (or its officers) when the prospectus omits material information. Equals zero if the Distributor cannot be held criminally liable when the prospectus is misleading. Equals one-half if the Distributor can be held criminally liable when aware that the prospectus is misleading. Equals one if the Distributor can also be held criminally liable when negligently unaware that the prospectus is misleading.

An index of criminal sanctions applicable to the Accountant (or its officers) when the financial statements accompanying the prospectus omit material information. Equals zero if the Accountant cannot be held criminally liable when the financial statements accompanying the prospectus are misleading. Equals one-half if the Accountant can be held criminally liable when aware that the financial statement accompanying the prospectus are misleading. Equals one if the Accountant can also be held criminally liable when negligently unaware that the financial statements accompanying the prospectus are misleading.

The index of criminal sanctions equals the arithmetic mean of: (1) Criminal director; (2) Criminal distributor; and (3) Criminal accountant.

\section{Summary Indices of Enforcement}

The index of private enforcement equals the arithmetic mean of: (1) Disclosure Index; and (2) Burden of proof index.

The index of public enforcement equals the arithmetic mean of: (1) Supervisor characteristics index; (2) Investigative powers index; (3) Orders index; and (4) Criminal index. 


\section{Outcome Variables}

External cap / GDP

Domestic firms / pop

IPOs

Block premia

Access to equity

Earnings manipulation

Ownership Concentration

Anti-director rights

Efficiency of the judiciary

Log GDP per capita

Legal Origin

Investor

Protection
Average of the ratio of stock market capitalization held by small shareholders to gross domestic product for the period 1996-2000. The stock market capitalization held by small shareholders is computed as the product of the aggregate stock market capitalization and the average percentage of common shares not owned by the top three shareholders in the ten largest non-financial, privately-owned domestic firms in a given country. A firm is considered privately-owned if the State is not a known shareholder in it. Source: La Porta et al. (1999), HartlandPeel (1996) for Kenya, Bloomberg and various annual reports for Ecuador, Jordan, and Uruguay.

Logarithm of the average ratio of the number of domestic firms listed in a given country to its population (in millions) for the period 1996-2000. Source: International Finance Corporation: Emerging Markets Database (2001) and World Bank (2001).

Average of the ratio of the equity issued by newly-listed firms in a given country (in thousands) to its gross domestic product (in millions) over the period 1996-2000. Source: Securities Data Corporation, World Bank (2001).

"The block premia is computed taking the difference between the price per share paid for the control block and the exchange price two days after the announcement of the control transaction, dividing by the exchange price and multiplying by the ratio of the proportion of cash flow rights represented in the controlling block." We use the country's sample media. Source: Dyck and Zingales (2003).

Index of the extent to which business executives in a country agree with the statement "Stock markets are open to new firms and medium-sized firms". Scale from 1 (strongly agree) though 7 (strongly disagree). Source: Schwab et al. (1999).

Aggregate index of the pervasiveness of earnings management across countries between 1990 and 1999. Source: Leuz, Nanda, and Wysocki (2002).

Average percentage of common shares not owned by the top three shareholders in the ten largest non-financial, privately-owned domestic firms in a given country. A firm is considered privately-owned if the State is not a known shareholder in it. Source: La Porta et al. (1999), Hartland-Peel (1996) for Kenya, Bloomberg and various annual reports for Ecuador, Jordan, and Uruguay.

\section{Control Variables and Instruments}

This index of Anti-director rights is formed by adding one when: (1) the country allows shareholders to mail their proxy vote; (2) shareholders are not required to deposit their shares prior to the General Shareholders' Meeting; (3) cumulative voting or proportional representation of minorities on the board of directors is allowed; (4) an oppressed minorities mechanism is in place; (5) the minimum percentage of share capital that entitles a shareholder to call for an Extraordinary Shareholders' Meeting is less than or equal to ten percent (the sample median); or (6) when shareholders have preemptive rights that can only be waved by a shareholders meeting. The range for the index is from zero to six. Source: La Porta et al. (1998).

Assessment of the "efficiency and integrity of the legal environment as it affects business, particularly foreign firms" produced by the country risk rating agency International Country Risk (ICR). It may be "taken to represent investors' assessment of conditions in the country in question." Average between 1980 and 1983. Scale from 0 to 10, with lower scores representing lower efficiency levels. Source: International Country Risk Guide.

Logarithmic of per capita Gross Domestic Product (in US dollars) in 2000.

Identifies the legal origin of the company law or commercial code of each country. Source: La Porta, et al. (1999). Principal component of Private enforcement and Anti-director rights. Scale from 0 to 10. 
Table II - Indices of Regulation of Securities Markets

This table classifies countries by legal origin and shows the securities law variables for each country covering the areas of: (1) disclosure requirements; (2) burden of the proof; (3) private enforcement; (4) characteristics of the supervisor; (5) investigative powers of the supervisor; (6) orders to issuers, distributors, and accountants; (7) criminal sanctions applicable to issuers, distributors, and accountants; and (8) public enforcement. All variables are described in Table 1 .

\begin{tabular}{|c|c|c|c|c|c|c|c|c|}
\hline & $\begin{array}{c}\text { Disclosure } \\
\text { requirements }\end{array}$ & Burden of proof & $\begin{array}{c}\text { Private } \\
\text { enforcement }\end{array}$ & $\begin{array}{l}\text { Supervisor } \\
\text { attributes }\end{array}$ & $\begin{array}{c}\text { Investigative } \\
\text { powers }\end{array}$ & Orders & $\begin{array}{l}\text { Criminal } \\
\text { sanctions }\end{array}$ & $\begin{array}{c}\text { Public } \\
\text { enforcement }\end{array}$ \\
\hline \multicolumn{9}{|l|}{ English legal origin } \\
\hline Australia & 0.75 & 0.66 & 0.71 & 0.75 & 1.00 & 1.00 & 0.83 & 0.90 \\
\hline Canada & 0.92 & 1.00 & 0.96 & 0.63 & 1.00 & 1.00 & 0.83 & 0.86 \\
\hline Hong Kong & 0.92 & 0.66 & 0.79 & 0.50 & 1.00 & 1.00 & 1.00 & 0.88 \\
\hline India & 0.92 & 0.66 & 0.79 & 0.38 & 1.00 & 0.67 & 0.83 & 0.72 \\
\hline Ireland & 0.67 & 0.55 & 0.61 & 0.25 & 0.00 & 0.00 & 0.83 & 0.27 \\
\hline Israel & 0.67 & 0.66 & 0.67 & 0.50 & 1.00 & 1.00 & 0.50 & 0.75 \\
\hline Kenya & 0.50 & 0.44 & 0.47 & 0.50 & 0.50 & 1.00 & 0.67 & 0.67 \\
\hline Malaysia & 0.92 & 0.66 & 0.79 & 0.38 & 1.00 & 1.00 & 1.00 & 0.84 \\
\hline New Zealand & 0.67 & 0.44 & 0.55 & 0.25 & 1.00 & 0.00 & 0.33 & 0.40 \\
\hline Nigeria & 0.67 & 0.44 & 0.55 & 0.63 & 0.00 & 0.00 & 0.50 & 0.28 \\
\hline Pakistan & 0.58 & 0.44 & 0.51 & 0.75 & 1.00 & 0.17 & 0.08 & 0.50 \\
\hline Singapore & 1.00 & 0.66 & 0.83 & 0.50 & 1.00 & 1.00 & 1.00 & 0.88 \\
\hline South Africa & 0.83 & 0.66 & 0.75 & 0.25 & 0.50 & 0.00 & 0.42 & 0.29 \\
\hline Sri Lanka & 0.75 & 0.44 & 0.60 & 0.50 & 0.50 & 0.00 & 0.33 & 0.33 \\
\hline Thailand & 0.92 & 0.33 & 0.63 & 0.75 & 1.00 & 0.33 & 0.58 & 0.67 \\
\hline United Kingdom & 0.83 & 0.66 & 0.75 & 0.25 & 1.00 & 1.00 & 0.42 & 0.67 \\
\hline United States & 1.00 & 1.00 & 1.00 & 1.00 & 1.00 & 1.00 & 0.50 & 0.88 \\
\hline Zimbabwe & 0.50 & 0.44 & 0.47 & 0.75 & 0.00 & 0.08 & 1.00 & 0.46 \\
\hline Mean & 0.78 & 0.60 & 0.69 & 0.53 & 0.75 & 0.57 & 0.65 & 0.63 \\
\hline \multicolumn{9}{|l|}{ French legal origin } \\
\hline Argentina & 0.50 & 0.22 & 0.36 & 0.75 & 1.00 & 0.08 & 0.17 & 0.50 \\
\hline Belgium & 0.42 & 0.44 & 0.43 & 0.00 & 0.25 & 0.00 & 0.50 & 0.19 \\
\hline Brazil & 0.25 & 0.33 & 0.29 & 0.50 & 0.50 & 0.75 & 0.33 & 0.52 \\
\hline Chile & 0.58 & 0.33 & 0.46 & 0.50 & 0.75 & 0.42 & 0.50 & 0.54 \\
\hline Colombia & 0.42 & 0.11 & 0.26 & 0.50 & 0.75 & 0.33 & 0.50 & 0.52 \\
\hline Ecuador & 0.00 & 0.22 & 0.11 & 1.00 & 0.25 & 0.08 & 0.42 & 0.44 \\
\hline Egypt & 0.50 & 0.22 & 0.36 & 0.50 & 0.25 & 0.17 & 0.42 & 0.33 \\
\hline France & 0.75 & 0.22 & 0.49 & 0.88 & 1.00 & 1.00 & 0.33 & 0.80 \\
\hline Greece & 0.33 & 0.44 & 0.39 & 0.50 & 0.25 & 0.17 & 0.50 & 0.35 \\
\hline Indonesia & 0.50 & 0.66 & 0.58 & 0.50 & 1.00 & 0.25 & 0.50 & 0.56 \\
\hline Italy & 0.67 & 0.22 & 0.44 & 0.75 & 0.25 & 0.00 & 0.50 & 0.38 \\
\hline Jordan & 0.67 & 0.22 & 0.44 & 0.50 & 1.00 & 0.67 & 0.00 & 0.54 \\
\hline Mexico & 0.58 & 0.11 & 0.35 & 0.25 & 0.25 & 0.00 & 0.50 & 0.25 \\
\hline Netherlands & 0.50 & 1.00 & 0.75 & 0.50 & 0.50 & 0.00 & 0.50 & 0.38 \\
\hline Peru & 0.33 & 0.66 & 0.50 & 0.75 & 0.75 & 1.00 & 0.50 & 0.75 \\
\hline Philippines & 0.83 & 1.00 & 0.92 & 0.75 & 1.00 & 1.00 & 0.50 & 0.81 \\
\hline Portugal & 0.42 & 0.66 & 0.54 & 0.75 & 1.00 & 0.25 & 0.00 & 0.50 \\
\hline Spain & 0.50 & 0.66 & 0.58 & 0.50 & 0.50 & 0.00 & 0.50 & 0.38 \\
\hline Turkey & 0.50 & 0.22 & 0.36 & 0.75 & 1.00 & 0.00 & 0.50 & 0.56 \\
\hline Uruguay & 0.00 & 0.11 & 0.06 & 0.75 & 0.25 & 0.50 & 0.42 & 0.48 \\
\hline Venezuela & 0.17 & 0.22 & 0.19 & 0.50 & 1.00 & 0.08 & 0.33 & 0.48 \\
\hline Mean & 0.45 & 0.39 & 0.42 & 0.59 & 0.64 & 0.32 & 0.40 & 0.49 \\
\hline \multicolumn{9}{|l|}{ German legal origin } \\
\hline Austria & 0.25 & 0.11 & 0.18 & 0.25 & 0.00 & 0.00 & 0.50 & 0.19 \\
\hline Germany & 0.42 & 0.00 & 0.21 & 0.25 & 0.25 & 0.00 & 0.50 & 0.25 \\
\hline Japan & 0.75 & 0.66 & 0.71 & 0.00 & 0.00 & 0.00 & 0.00 & 0.00 \\
\hline Korea & 0.75 & 0.66 & 0.71 & 0.25 & 0.50 & 0.08 & 0.33 & 0.29 \\
\hline Switzerland & 0.67 & 0.44 & 0.55 & 0.50 & 0.00 & 0.00 & 0.33 & 0.21 \\
\hline Taiwan & 0.75 & 0.66 & 0.71 & 0.50 & 0.25 & 0.17 & 0.83 & 0.44 \\
\hline Mean & 0.60 & 0.42 & 0.51 & 0.29 & 0.17 & 0.04 & 0.42 & 0.23 \\
\hline \multicolumn{9}{|l|}{ Scandinavian legal origin } \\
\hline Denmark & 0.58 & 0.78 & 0.68 & 0.25 & 0.50 & 0.33 & 0.00 & 0.27 \\
\hline Finland & 0.50 & 0.66 & 0.58 & 0.50 & 0.25 & 0.17 & 0.50 & 0.35 \\
\hline Norway & 0.58 & 0.44 & 0.51 & 0.00 & 0.25 & 0.33 & 1.00 & 0.40 \\
\hline Sweden & 0.58 & 0.33 & 0.46 & 0.25 & 0.25 & 0.67 & 0.58 & 0.44 \\
\hline Mean & 0.56 & 0.55 & 0.56 & 0.25 & 0.31 & 0.38 & 0.52 & 0.37 \\
\hline \multirow[t]{2}{*}{ Mean for all countries } & 0.60 & 0.49 & 0.54 & 0.50 & 0.60 & 0.38 & 0.50 & 0.48 \\
\hline & \multicolumn{8}{|c|}{ Tests of means (t-stats) } \\
\hline English vs. Civil Law & $-5.01^{\mathrm{a}}$ & $-2.52^{\mathrm{b}}$ & $-4.25^{\mathrm{a}}$ & -0.56 & $-2.23^{\mathrm{b}}$ & $-2.60^{\mathrm{a}}$ & $-3.18^{\mathrm{a}}$ & $-3.38^{\mathrm{a}}$ \\
\hline English vs. French & $-5.31^{\mathrm{a}}$ & $-2.70^{\mathrm{a}}$ & $-4.66^{\mathrm{a}}$ & 0.88 & -0.92 & $-1.87^{\mathrm{c}}$ & $-3.46^{\mathrm{a}}$ & $-2.12^{\mathrm{b}}$ \\
\hline English vs. German & $-2.19^{b}$ & $-1.76^{\mathrm{c}}$ & $-2.10^{\mathrm{b}}$ & $-2.38^{\mathrm{b}}$ & $-3.45^{\mathrm{a}}$ & $-2.70^{\mathrm{a}}$ & $-1.77^{\mathrm{c}}$ & $-3.86^{\mathrm{a}}$ \\
\hline English vs. Scandinavian & $-2.60^{\mathrm{b}}$ & -0.47 & $-1.61^{\mathrm{c}}$ & $-2.34^{\mathrm{b}}$ & $-2.17^{\mathrm{b}}$ & -0.80 & -0.76 & $-2.16^{\mathrm{b}}$ \\
\hline French vs. German & $1.49^{\mathrm{c}}$ & 0.21 & 0.91 & $-3.00^{\mathrm{a}}$ & $-3.32^{\mathrm{a}}$ & $-1.87^{\mathrm{c}}$ & 0.18 & $-3.55^{\mathrm{a}}$ \\
\hline French vs. Scandinavian & 1.03 & 1.08 & 1.34 & $-2.85^{\mathrm{a}}$ & $-1.94^{\mathrm{c}}$ & 0.29 & 1.05 & -1.49 \\
\hline German vs. Scandinavian & -0.32 & 0.75 & 0.36 & -0.33 & 1.26 & $3.70^{\mathrm{a}}$ & 0.49 & $1.73^{\mathrm{c}}$ \\
\hline
\end{tabular}

$\mathrm{a}=$ significant at $1 \%$ level; $\mathrm{b}=$ significant at $5 \%$ level; $\mathrm{c}=$ significant at $10 \%$ level. 


\section{Table III - Securities Regulation and External Market Capitalization}

Ordinary least squares regressions of the cross-section of countries. The dependent variables is External market capitalization. We report six regressions successively controlling for the following securities laws variables: (1) Disclosure requirements; (2) Burden of proof; (3) Supervisor attributes; (4) Investigative powers; (5) Orders; and (6) Criminal sanctions. In addition to a securities laws variables, all regressions include Anti-director rights, Log of GDP per capita, and Efficiency of the judiciary. Robust standard errors are shown in parentheses. All variables are described in Table 1.

\begin{tabular}{lcccccc}
\hline & $\begin{array}{c}\text { Disclosure } \\
\text { requirements }\end{array}$ & $\begin{array}{c}\text { Burden of } \\
\text { Proof }\end{array}$ & $\begin{array}{c}\text { Supervisor } \\
\text { characteristics }\end{array}$ & $\begin{array}{c}\text { Investigative } \\
\text { powers }\end{array}$ & Orders & $\begin{array}{c}\text { Criminal } \\
\text { sanctions }\end{array}$ \\
\hline Securities regulation variable & $0.5813^{\mathrm{a}}$ & $0.4093^{\mathrm{a}}$ & 0.1858 & 0.0525 & 0.1207 & 0.1336 \\
& $(0.1377)$ & $(0.1311)$ & $(0.1770)$ & $(0.1236)$ & $(0.1112)$ & $(0.1643)$ \\
Anti-director Rights & 0.0420 & 0.0568 & $0.0894^{\mathrm{b}}$ & $0.0878^{\mathrm{a}}$ & $0.0803^{\mathrm{b}}$ & $0.0877^{\mathrm{a}}$ \\
& $(0.0308)$ & $(0.0339)$ & $(0.0336)$ & $(0.0310)$ & $(0.0312)$ & $(0.0303)$ \\
Efficiency judicial system & $0.0386^{\mathrm{c}}$ & $0.0444^{\mathrm{c}}$ & $0.0548^{\mathrm{b}}$ & $0.0496^{\mathrm{c}}$ & $0.0412^{\mathrm{c}}$ & $0.0430^{\mathrm{c}}$ \\
& $(0.0204)$ & $(0.0225)$ & $(0.0269)$ & $(0.0249)$ & $(0.0243)$ & $(0.0252)$ \\
Log GDP per capita & $0.0957^{\mathrm{a}}$ & $0.0899^{\mathrm{a}}$ & $0.1023^{\mathrm{a}}$ & $0.0987^{\mathrm{a}}$ & $0.1041^{\mathrm{a}}$ & $0.1018^{\mathrm{a}}$ \\
& $(0.0229)$ & $(0.0241)$ & $(0.0242)$ & $(0.0245)$ & $(0.0219)$ & $(0.0265)$ \\
Constant & $-1.2056^{\mathrm{a}}$ & $-1.0951^{\mathrm{a}}$ & $-1.2758^{\mathrm{a}}$ & $-1.1377^{\mathrm{a}}$ & $-1.1129^{\mathrm{a}}$ & $-1.1506^{\mathrm{a}}$ \\
& $(0.2037)$ & $(0.2055)$ & $(0.2594)$ & $(0.2021)$ & $(0.2003)$ & $(0.2410)$ \\
\hline Observations & 49 & 49 & 49 & 49 & 49 & 49 \\
Adjusted $\mathrm{R}^{2}$ & 0.54 & 0.51 & 0.46 & 0.45 & 0.46 & 0.45 \\
\hline
\end{tabular}

$\mathrm{a}=$ significant at 1 percent level; $\mathrm{b}=$ significant at 5 percent level; $\mathrm{c}=$ significant at 10 percent level. 


\section{Table IV - Public Versus Private Enforcement}

Ordinary least squares regressions of the cross-section of countries. The dependent variables are: (1) External market capitalization ratio; (2) Log of domestic firms per capita; (3) Value of IPOs; (4) Block premia; (5) Access to equity; (6) Earnings manipulation; and (7) Ownership concentration. For each dependent variable, we report three regressions successively controlling for the following securities laws variables: (1) Private enforcement (Panel A); (2) Public enforcement (Panel B); and (3) both Private and Public enforcement (Panel C). In addition to the securities laws variables, all regressions include Anti-director rights, Log of GDP per capita, and Efficiency of the judiciary. Robust standard errors are shown in parentheses. All variables are described in Table 1.

Panel A: Private Enforcement

\begin{tabular}{|c|c|c|c|c|c|c|c|}
\hline & $\begin{array}{c}\text { Market } \\
\text { capitalization }\end{array}$ & $\begin{array}{c}\text { Number of } \\
\text { firms }\end{array}$ & IPOs & Block premia & $\begin{array}{c}\text { Access to } \\
\text { equity }\end{array}$ & $\begin{array}{c}\text { Earnings } \\
\text { manipulation }\end{array}$ & $\begin{array}{c}\text { Ownership } \\
\text { concentration }\end{array}$ \\
\hline \multirow[t]{2}{*}{ Private enforcement } & $0.7113^{\mathrm{a}}$ & $1.3100^{\mathrm{b}}$ & $5.5700^{\mathrm{a}}$ & $-0.2818^{b}$ & $2.3605^{\mathrm{a}}$ & $-12.4908^{c}$ & $-0.2306^{\mathrm{b}}$ \\
\hline & $(0.1535)$ & $(0.4913)$ & $(1.5166)$ & $(0.1049)$ & $(0.5610)$ & $(7.2779)$ & $(0.0962)$ \\
\hline \multirow[t]{2}{*}{ Anti-director rights } & 0.0298 & 0.1005 & 0.0545 & -0.0152 & -0.1258 & -1.5398 & -0.0174 \\
\hline & $(0.0334)$ & $(0.0940)$ & $(0.3098)$ & $(0.0157)$ & $(0.0799)$ & $(0.9045)$ & $(0.0131)$ \\
\hline \multirow[t]{2}{*}{ Efficiency judicial system } & $0.0396^{\mathrm{b}}$ & $0.2326^{\mathrm{a}}$ & -0.0744 & -0.0051 & $0.1828^{\mathrm{a}}$ & -0.3941 & -0.0074 \\
\hline & $(0.0196)$ & $(0.0696)$ & $(0.1970)$ & $(0.0117)$ & $(0.0582)$ & $(0.7531)$ & $(0.0094)$ \\
\hline \multirow[t]{2}{*}{ Log GDP per capita } & $0.0889^{a}$ & $0.2668^{b}$ & $1.0875^{\mathrm{a}}$ & -0.0062 & 0.1378 & -0.6236 & $-0.0263^{c}$ \\
\hline & $(0.0223)$ & $(0.1082)$ & $(0.2297)$ & $(0.0217)$ & $(0.0903)$ & $(1.3012)$ & $(0.0140)$ \\
\hline \multirow[t]{2}{*}{ Constant } & $-1.1558^{\mathrm{a}}$ & $-2.5775^{\mathrm{a}}$ & $-9.1621^{\mathrm{a}}$ & $0.4071^{b}$ & $1.5276^{\mathrm{b}}$ & $37.7485^{\mathrm{a}}$ & $0.9370^{\mathrm{a}}$ \\
\hline & $(0.1967)$ & $(0.7167)$ & $(1.7745)$ & $(0.1636)$ & $(0.7095)$ & $(9.4019)$ & $(0.1002)$ \\
\hline Observations & 49 & 49 & 49 & 37 & 44 & 29 & 49 \\
\hline Adjusted $\mathrm{R}^{2}$ & 0.56 & 0.69 & 0.39 & 0.32 & 0.57 & 0.25 & 0.37 \\
\hline
\end{tabular}

Panel B: Public Enforcement

\begin{tabular}{|c|c|c|c|c|c|c|c|}
\hline & $\begin{array}{c}\text { Market } \\
\text { capitalization }\end{array}$ & $\begin{array}{l}\text { Number of } \\
\text { firms }\end{array}$ & IPOs & Block premia & $\begin{array}{c}\text { Access to } \\
\text { equity }\end{array}$ & $\begin{array}{c}\text { Earnings } \\
\text { manipulation }\end{array}$ & $\begin{array}{c}\text { Ownership } \\
\text { concentration }\end{array}$ \\
\hline \multirow[t]{2}{*}{ Public enforcement } & 0.2525 & $0.9491^{b}$ & $3.5689^{b}$ & -0.0212 & 0.3107 & -8.5273 & 0.0774 \\
\hline & $(0.2054)$ & $(0.4531)$ & $(1.6541)$ & $(0.0689)$ & $(0.5688)$ & $(6.0478)$ & $(0.0866)$ \\
\hline \multirow[t]{2}{*}{ Anti-director rights } & $0.0747^{\mathrm{b}}$ & 0.1460 & 0.2836 & $-0.0401^{b}$ & 0.0643 & $-1.7566^{c}$ & $-0.0442^{\mathrm{a}}$ \\
\hline & $(0.0325)$ & $(0.0873)$ & $(0.2626)$ & $(0.0152)$ & $(0.1119)$ & $(0.9260)$ & $(0.0125)$ \\
\hline \multirow[t]{2}{*}{ Efficiency judicial system } & $0.0480^{\mathrm{b}}$ & $0.2499^{\mathrm{a}}$ & -0.0026 & -0.0038 & $0.1899^{\mathrm{b}}$ & -0.5103 & -0.0095 \\
\hline & $(0.0234)$ & $(0.0711)$ & $(0.2136)$ & $(0.0123)$ & $(0.0731)$ & $(0.7458)$ & $(0.0110)$ \\
\hline \multirow[t]{2}{*}{ Log GDP per capita } & $0.1034^{\mathrm{a}}$ & $0.3013^{\mathrm{a}}$ & $1.2267^{\mathrm{a}}$ & -0.0144 & 0.1982 & -0.7688 & $-0.0284^{\mathrm{c}}$ \\
\hline & $(0.0221)$ & $(0.1034)$ & $(0.2668)$ & $(0.0219)$ & $(0.1257)$ & $(1.2831)$ & $(0.0153)$ \\
\hline \multirow[t]{2}{*}{ Constant } & $-1.2210^{\mathrm{a}}$ & $-2.9110^{\mathrm{a}}$ & $-10.3742^{a}$ & $0.3995^{\mathrm{b}}$ & 1.5136 & $37.3778^{\mathrm{a}}$ & $0.8880^{\mathrm{a}}$ \\
\hline & $(0.2084)$ & $(0.7264)$ & $(1.9645)$ & $(0.1812)$ & (1.0289) & $(10.2820)$ & $(0.1093)$ \\
\hline Observations & 49 & 49 & 49 & 37 & 44 & 29 & 49 \\
\hline Adjusted $\mathrm{R}^{2}$ & 0.46 & 0.67 & 0.34 & 0.15 & 0.38 & 0.24 & 0.29 \\
\hline
\end{tabular}


Panel C: Private and Public Enforcement

\begin{tabular}{|c|c|c|c|c|c|c|c|}
\hline & $\begin{array}{c}\text { Market } \\
\text { capitalization }\end{array}$ & $\begin{array}{l}\text { Number of } \\
\text { firms }\end{array}$ & IPOs & Block premia & $\begin{array}{c}\text { Access to } \\
\text { equity }\end{array}$ & $\begin{array}{c}\text { Earnings } \\
\text { manipulation }\end{array}$ & $\begin{array}{l}\text { Ownership } \\
\text { concentration }\end{array}$ \\
\hline \multirow[t]{2}{*}{ Private Enforcement } & $0.6849^{\mathrm{a}}$ & $1.0900^{\mathrm{b}}$ & $4.7998^{a}$ & $-0.3100^{\mathrm{a}}$ & $2.5366^{\mathrm{a}}$ & -9.0592 & $-0.2784^{\mathrm{a}}$ \\
\hline & $(0.1681)$ & $(0.5260)$ & $(1.6681)$ & $(0.1128)$ & $(0.6580)$ & (7.7796) & $(0.0998)$ \\
\hline \multirow[t]{2}{*}{ Public Enforcement } & 0.0814 & 0.6767 & 2.3692 & 0.0702 & -0.4469 & -5.4508 & 0.1469 \\
\hline & $(0.2062)$ & $(0.4723)$ & $(1.8046)$ & $(0.0689)$ & $(0.6966)$ & $(6.8066)$ & $(0.0951)$ \\
\hline \multirow[t]{2}{*}{ Anti-director rights } & 0.0259 & 0.0684 & -0.0579 & -0.0187 & -0.1049 & -1.2825 & $-0.0244^{c}$ \\
\hline & $(0.0324)$ & $(0.0980)$ & $(0.2988)$ & $(0.0148)$ & $(0.0898)$ & $(1.0207)$ & $(0.0135)$ \\
\hline \multirow[t]{2}{*}{ Efficiency judicial system } & $0.0402^{b}$ & $0.2376^{\mathrm{a}}$ & -0.0568 & -0.0061 & $0.1845^{\mathrm{a}}$ & -0.4468 & -0.0063 \\
\hline & $(0.0198)$ & $(0.0672)$ & $(0.2043)$ & $(0.0119)$ & $(0.0582)$ & $(0.7566)$ & $(0.0096)$ \\
\hline \multirow[t]{2}{*}{ Log GDP per capita } & $0.0907^{\mathrm{a}}$ & $0.2810^{\mathrm{b}}$ & $1.1375^{\mathrm{a}}$ & -0.0005 & 0.1129 & -0.7772 & $-0.0232^{\mathrm{c}}$ \\
\hline & $(0.0213)$ & $(0.1053)$ & $(0.2371)$ & $(0.0235)$ & $(0.0944)$ & $(1.2605)$ & $(0.0133)$ \\
\hline \multirow{2}{*}{ Constant } & $-1.1899^{a}$ & $-2.8616^{a}$ & $-10.1569^{a}$ & $0.3538^{c}$ & $1.8034^{\mathrm{b}}$ & $39.4791^{\mathrm{a}}$ & $0.8753^{\mathrm{a}}$ \\
\hline & $(0.2099)$ & $(0.7570)$ & $(1.9611)$ & $(0.1802)$ & $(0.7371)$ & $(9.6686)$ & $(0.1089)$ \\
\hline Observations & 49 & 49 & 49 & 37 & 44 & 29 & 49 \\
\hline Adjusted $\mathrm{R}^{2}$ & 0.55 & 0.70 & 0.39 & 0.32 & 0.57 & 0.24 & 0.40 \\
\hline
\end{tabular}

$\mathrm{a}=$ significant at 1 percent level; $\mathrm{b}=$ significant at 5 percent level; $\mathrm{c}=$ significant at 10 percent level 
Table V - Instrumental Variables Regressions

Two-stage least squares regressions of the cross-section of countries. The dependent variables are: (1) External market capitalization; (2) Log of domestic firms per capita; (3) Value of IPOs; (4) Block premia; (5) Access to equity; (6) Earnings manipulation; and (7) Ownership concentration. Investor protection is the principal component of Private enforcement and Anti-director rights. In addition to Investor protection, all regressions include Log of GDP per capita and Efficiency of the judiciary. The instrument is a dummy equal to one if the country's legal origin is common law. All variables are described in Table 1. Robust standard errors are shown in parentheses.

\begin{tabular}{|c|c|c|c|c|c|c|c|}
\hline & $\begin{array}{c}\text { Market } \\
\text { capitalization }\end{array}$ & Domestic firms & IPOs & Block premia & $\begin{array}{c}\text { Access to } \\
\text { equity }\end{array}$ & $\begin{array}{c}\text { Earnings } \\
\text { manipulation }\end{array}$ & $\begin{array}{l}\text { Ownership } \\
\text { concentration }\end{array}$ \\
\hline \multirow[t]{2}{*}{ Investor protection } & $0.0540^{\mathrm{b}}$ & $0.1875^{\mathrm{a}}$ & $0.5946^{\mathrm{a}}$ & $-0.0207^{b}$ & $0.1271^{\mathrm{b}}$ & $-1.7408^{c}$ & $-0.0154^{\mathrm{c}}$ \\
\hline & $(0.0248)$ & $(0.0667)$ & $(0.2178)$ & $(0.0091)$ & $(0.0586)$ & $(0.8493)$ & $(0.0090)$ \\
\hline \multirow[t]{2}{*}{ Investor protection } & $0.1122^{b}$ & $0.3898^{\mathrm{a}}$ & $1.2360^{\mathrm{a}}$ & $-0.0429^{b}$ & $0.2642^{\mathrm{b}}$ & $-3.6186^{c}$ & $-0.0319^{c}$ \\
\hline & $(0.0515)$ & $(0.1386)$ & $(0.4527)$ & $(0.0189)$ & $(0.1219)$ & $(1.7653)$ & $(0.0187)$ \\
\hline \multirow[t]{2}{*}{ Efficiency judicial system } & $0.0432^{\mathrm{c}}$ & $0.2100^{\mathrm{b}}$ & -0.1607 & -0.0062 & $0.1599^{\mathrm{b}}$ & -0.2617 & -0.0112 \\
\hline & $(0.0223)$ & $(0.0812)$ & $(0.2054)$ & $(0.0117)$ & $(0.0743)$ & $(0.8560)$ & $(0.0098)$ \\
\hline \multirow[t]{2}{*}{ Log GDP per capita } & $0.0939^{\mathrm{a}}$ & $0.2850^{\mathrm{b}}$ & $1.1884^{\mathrm{a}}$ & -0.0081 & 0.1816 & -0.8263 & $-0.0262^{c}$ \\
\hline & $(0.0217)$ & $(0.1131)$ & $(0.2562)$ & $(0.0194)$ & $(0.1112)$ & $(1.5205)$ & $(0.0145)$ \\
\hline \multirow[t]{2}{*}{ Constant } & $-1.0013 \mathrm{a}$ & $-2.4199^{a}$ & $-8.9534^{\mathrm{a}}$ & $0.3277^{\mathrm{b}}$ & $1.6506^{c}$ & $35.2472^{\mathrm{a}}$ & $0.8591^{\mathrm{a}}$ \\
\hline & $(0.1895)$ & $(0.7312)$ & $(1.6884)$ & $(0.1470)$ & $(0.8490)$ & $(12.2430)$ & $(0.0919)$ \\
\hline Observations & 49 & 49 & 49 & 37 & 44 & 29 & 49 \\
\hline R-squared & 0.57 & 0.70 & 0.39 & 0.36 & 0.51 & 0.35 & 0.39 \\
\hline
\end{tabular}

$\mathrm{a}=$ significant at 1 percent level; $\mathrm{b}=$ significant at 5 percent level; $\mathrm{c}=$ significant at 10 percent level. 